Janis Pleps

\title{
Fundamental Rights and Latvian Constitution (1918-1934)
}

Keywords: Latvia, constitution, fundamental rights

\begin{abstract}
Summary
The Latvian road towards inclusion of the fundamental rights catalogue in the constitution started with proclamation of the state on November 18, 1918. The initial transitional constitutions already included according to their laconic style rather extensive guarantees of the fundamental rights. Mostly that means guarantees for national minorities.

In the inter-war period, the catalogue of the fundamental rights was not considered as a significant component of the constitution content. The norms of the catalogue were generally perceived as "declarative slogans", which had little practical significance. Much greater importance was assigned by the politicians and jurists to the laws adopted by the parliament with regards to the procedure of implementing certain fundamental rights.

Latvian Constitutional Assembly has included "The Basic regulations regarding rights and regulations of the citizens" as a second part of the Constitution. The German Weimar Constitution of August 11, 1919 was used as a pattern for the draft of this part of the Constitution. The draft of the second part of Constitution prescribed a range of civic and political individual rights and freedoms. Parallel to that, the draft of the second part of the Constitution contained articles, which prescribed the state responsibility to protect the nationally-cultural autonomy of minorities, monuments of art, history, and nature, as well as marriage as the foundation of the family. The second part of the Constitution also dealt with the some social matters.

Unfortunately, the second part of the Constitution was not adopted, leaving the regulation of this matter for the upcoming generations, which was completed only ten years ago.
\end{abstract}




\section{Introduction}

On October 15, 1998, the 6th Saeima (Parliament) of the Republic of Latvia, adopted the amendments in the Constitution of the Republic of Latvia, which supplemented the Constitution with a new - eighth chapter "Fundamental Human Rights"'. Only slightly more than ten years have passed since the catalogue of fundamental rights was included in the Constitution of the Republic of Latvia ${ }^{2}$. At the same time, more than ninety years have passed since the independent state of Latvia has been in existence.

The origins of the constitutional regulation for the fundamental rights are one of the most complicated matters in the history of constitutional law of Latvia. The fact that only on October 15, 1998 the Constitution was supplemented with the catalogue of fundamental rights does not imply that before the given date the fundamental rights in Latvia did not hold a constitutional rank or that in Latvia implementation of catalogue of fundamental rights adequate for a democratic state governed by law was not fully ensured.

\section{First Transitional Constitution}

\section{Political Platform of National Council}

On November 17, 1918, the representatives of Latvian political parties at deciding about establishment of the state, announced themselves to be the Latvian National Council, which up to the convening of the Constitutional Assembly possessed the sovereign state power, as well as adopted the Political platform of the Latvian National Council ${ }^{3}$. As commented by the secretary of the National Council, Erasts Bite - "it is very short, as consists only of 7 Articles"4. Upon evaluation of the said deed, it must be taken into account, that it was elaborated in hurry and it "combines to tasks: to provide with the main provisions of the transitional constitution and to set forth the most important items of the operational programme of the temporary government"s. Therefore, in assessment of the Political platform of the National Council, it must be considered that it regulates the basic issues of a political system only partially, while paying extensive attention to the political objectives of the temporary government before the

1 Grozījumi Latvijas Republikas Satversmē,(„Latvijas Vēstnesis” 1998, no. 308/312.

2 Latvijas Republikas Satversme, „Valdïbas Vēstnesis” 1922, no. 141). Constitution of Republic of Latvia in English: http://www.satv.tiesa.gov.lv/?lang=2\&mid=8.

${ }^{3}$ Latvijas Tautas padomes politiskā platforma,(„Pagaidu Valdības Vēstnesis” 1918, no. 1.

4 E. Bite, Latvijas pagaidu konstitūcija, „Jaunā Latvija” 8. marts 1920.

5 K. Dišlers, Latvijas Republikas Satversmes attīstība, [in:] Latvija desmit gados. Latvijas valsts nodibināšanas un viņas pirmo 10 gadu darbības vēsture, ed. M. Ārons, Jubilejas komisijas izdevums, Rīga 1928, p. 73. 
summoning of the Constitutional Assembly. In this aspect, the political platform of the National Council radically differed from the first temporary constitutions of the neighbouring states - Lithuania ${ }^{6}$ and Poland ${ }^{7}$. Commenting the political platform of the National Council, the associate professor, Ringolds Balodis, has justifiably written: "The constitutional standards included therein were too loose and superficial. [...] It is indicative of the vast ideologically political significance of the document, rather than of a serious legal value thereof".

However meanwhile, two of the seven sections of the political platform of the National Council were devoted to the fundamental rights. Section IV ${ }^{9}$ of the political platform of the National Council set forth the rights of non-residents, while Section $\mathrm{V}^{10}$ prescribed the civic freedoms. When commenting the political platform of the National Council, the professor Kārlis Dišlers has indicated with this respect the following: "At first, the rights of the national minorities to participate in the National Council and the temporary government have been recognised - as it can be seen, with the intention to involve also the non-residents already from the very beginning in the very difficult and important work of organising the state. The national minorities are granted with recognised political rights (general, equal, direct, proportional elections by secret ballot) and they are promised with ensuring of their cultural and national interests in the fundamental laws. The latter promise, of course, could not bind the Constitutional Assembly, and in the adopted Constitution, we cannot find any guarantees of rights for the national minorities, which, naturally, does not imply that these rights are denied or restricted. The fifth section contains a promise to ensure the freedom of speech, meetings, and assembling subject to the statutory conditions"11.

6 Lietuvos Valstybès Laikinosios Konstitucijos pamatiniai dèsniai (M. Maksimaitis, Lietuvos valstybès konstituciju istorija (XX a. pirmoji puse)), Justitia, Vilnius 2005, p. 323-325).

7 V. Gribovskis, Polijas republikas satversme, „Tieslietu Ministrijas Vēstnesis” 1923, no. 1, p. 174-175 .

8 R. Balodis, Latvijas Republikas konstitucionālo tiesību evolūcija un transformācija 20.-21. gadsimta mijā, [in:] Tiesību harmonizācija Baltijas jūras reǵionā 20.-21. gadsimta mijā. Starptautiskā zinātniskā conference, Latvijas Universitātes Juridiskā fakultāte, Rīga 2006, p. 445.

9 „IV. Rights of national minorities:

1) National minorities delegate their representatives in the Constitutional Assembly and legislative institutions on the basis of proportional election rights (see Art. 1. 2).

2) National minorities, which are included in the Latvian National Council, participate in the Temporary Government on the grounds of the Paragraph 3 of Section III. laws".

3) The cultural and national rights of the national groups are to be ensured in the fundamental

${ }^{10}$ V. Civic Rights

1) The freedoms of press, speech, meeting, and assembling are to be ensured with the regulations of the Temporary Government.

2) Amnesty in all cases excluding crime.

3) Possibility for the citizens of the Republic of Latvia to return to homeland".

${ }^{11}$ K. Dišlers, Latvijas Republikas Satversmes attīstība, [in:] Latvija desmit gados. Latvijas valsts nodibināšanas un viņas pirmo 10 gadu darbības vēsture, ed. M. Ārons, Jubilejas komisijas izdevums, Rīga 1928, p. 73-74. 


\section{Proclamation Act}

Parallel to the norms included in the temporary constitution regarding the fundamental rights, the founders of the Latvian state stipulated on the subject also in the November 18, 1918 Proclamation Act of the Republic of Latvia. The Prime Minister Kārlis Ulmanis concluded his speech with the following utterance: "All citizens, without distinguishing between the nationality, are invited to assist, because the rights of all nationalities in Latvia will be ensured. It will be a country of democratic justice, where there can be no place for suppression or injustice"12. It has been recognised in the modern times that the speech of the Prime Minister portrays the political choice of the temporary government to create Latvia as a democratic, socially oriented country, where justice would prevail ${ }^{13}$. Such country, without a doubt, recognises and ensures both the rights of non-residents and the fundamental rights of a person. As has been written by the professor Aivars Endziņš, the values of a democratic judicial state were written in the red-white-and-red flag of Latvia in that November of the year 1918. "Also in those times, the idea of a judicial state was a self-evident and necessary element in the dream about statehood of Latvia"14.

This condition has been in its time precisely referred to by the judges of the Constitutional Court in their independent standpoints: "The state of Latvia from the very beginning of its foundation was in favour of democratic values, furthermore, it has connected understanding of the concept "democracy" with the experience of other democratic states. Thus, the temporary government, which was formed in 1918, declared with respect to the political and civic values, that its "objective for the purposes of state welfare is to ensure all rights of a democratic state to the inhabitants of Latvia. With persistent work, the government will implement in practice the rights of the citizens, such that all democratic states have long been enjoying". The temporary government also declared that it "does not wish to exercise suppression policy, but rather base itself on the principles of a modern democratic state". Furthermore, in elaborating and discussing the draft Constitution, the members of the Constitutional Assembly have referred on numerous occasions to the experience of the democratic states of the time, thus confirming the organic connection of the system to be formed in the state of Latvia with other progressive countries ${ }^{15}$.

${ }^{12}$ Latvijas valsts pasludināšana 18. novembrī 1918. g. Rakstu vainags H. J. sakopots, Apgādniecība „Astra” 1918, p. 19.

${ }^{13}$ J. Stradiņš, 18. novembra Ulmanis (Latvijas Republikas pirmais Ministru prezidents), [in:] Kārlim Ulmanim 125, Latvijas Vēstures institūta apgāds, Rīga 2003, p. 25.

${ }_{14}$ A. Endziņš, Tiesu sistèmas un politikas saskarsme un dinamika, „Jurista Vārds” 2002, no. 9, p. 242.

${ }^{15}$ Satversmes tiesas tiesnešu Aivara Endziṇa, Jura Jelāgina un Anitas Ušackas atsevišḳās domas lietā Nr. 2000-03-01 „Par Saeimas vēlēšanu likuma 5. panta 5. un 6. punkta un Pilsētu domes un pagastu padomes vēlěšanu likuma 9. panta 5. un 6. punkta atbilstîbu Latvijas Republikas Satversmes 89. un 101. pantam, Eiropas Cilvēka tiesību un pamatbrīvïbu aizsardzības konvencijas 14. pantam un 


\section{Second Transitional Constitution}

Upon meeting of the Latvian Constitutional Assembly on May 1, 1920, the Latvian Constitutional Assembly began the work at elaboration of the Constitution of the Republic of Latvia. Since this process was expected to last, the Latvian Constitutional Assembly initially adopted the second transitional constitution - the May 27, 1920 Declaration on the State of Latvia ${ }^{16}$ and the June 1, 1920 Transitional Regulations on Latvian Political System ${ }^{17}$.

The task of the transitional regulations, as it is implied by the name of the deed itself, was regulation of the temporary condition ${ }^{18}$. It was not intended to maintain these regulations effective for an extended period of time. The member of the Constitutional Assembly Jānis Purgals admitted: "The transitional regulations on Latvian political system are of temporary character, i.e., the will remain valid only until the final version of the Constitution will be elaborated by the Constitutional Assembly and adopted"19.

The transitional regulations of Latvian political system consisted of 12 articles, where in a laconic form the tasks and the term of office of the Latvian Constitutional Assembly were stipulated, as well as the reciprocal relations of the state authorities were regulated. Upon comparison of the political platform of the National Council, the relevant regulation was much mores specifically elaborated and reminded a text characteristic for constitutions.

The transitional regulations of the Latvian political system devoted Article 920 to the fundamental rights. Professor Kārlis Dišlers when commenting this norm, has laconically indicated: "In this concise deed, we find the guarantee of the most recognisable civic freedoms" ${ }^{21}$. He also has written: "Article 9 of the transitional regulations is of declarative character: it declares the so-called civic freedoms: immunity of a persona, residence, and correspondence, freedom of press, speech, cognition, strikes, meetings, and assembling, which are to be ensured with relevant legislation. Following the example of the "Human and civic rights declaration" of the Big French Revolution, similar declarative articles or

Starptautiskā pakta par pilsoṇu un politiskajām tiesībām 25. pantam”. Grām, Latvijas Republikas Satversmes tiesas spriedumi. 1999 - 2000, Tiesu Namu Aǵentūra, Rịga 2002, p. 118. Atsevišḳo domu 5. punkts.

${ }^{16}$ Deklarācija par Latvijas valsti, „Likumu un valdības rīkojumu krājums” 1920, no. 4.

${ }^{17}$ Latvijas valsts iekārtas pagaidu noteikumi, „Likumu un valdības rīkojumu krājums” 1920, no. 4.

${ }^{18}$ See also: K. Dišlers, Latvian Transitional Constitution. General Comments, „Tieslietu Ministrijas Vēstnesis" 1920, no. 2/3, p. 52.

${ }^{19}$ Report of September 20, 1921 1st meeting of session IV of the Latvian Constitutional Assembly.

${ }^{20}$ "In Latvia, there is the immunity of a persona and residence, freedom of press, speech, cognition, strike, meeting, and assembling, immunity of correspondence, which are to be ensured and established with the relevant laws".

${ }^{21}$ K. Dišlers, Latvijas Republikas Satversmes attīstība, [in:] Latvija desmit gados. Latvijas valsts nodibināšanas un viņas pirmo 10 gadu darbïbas vēsture, ed. M. Ārons, Jubilejas komisijas izdevums, Rīga 1928, p. 74. 
even whole sections of declarative character can be found in nearly all constitutions. In transitional times, when the said civic freedoms still have not been ensured with the relevant legislation, the practical importance of such declarative articles is insignificant, however the key value thereof still is preserved in the fact that the principles established therein are binding for the legislator. Likewise, the permanent significance of Article 9 of the Transitional Constitution of Latvia, implying that it is binding for the successive legislators, whose responsibility will be - "to set forth and ensure" the said civic freedoms, but who under no circumstances will not be allowed to infringe or restrict any of the principles of the civic freedoms as declared by the Constitutional Assembly"22.

\section{Second Part of Constitution}

\section{Elaboration of Second Part of Constitution}

The Constitutional Assembly, upon commencing the work on elaboration of the Constitution text, formed as special Constitutional Commission. In the $2^{\text {nd }}$ meeting of the Constitutional Commission, it was decided to create three subcommissions, which would elaborate a project on organization of the state authority, rights and obligations of the citizens, as well as regarding the procedure of elections for national representation ${ }^{23}$. It reflected the initial intent of that the Constitution would have three parts, which would regulate the organization of state authority, the rights and obligations of the citizens, as well as the procedure of parliamentary elections. Later the Constitutional Assembly withdrew from this plan and decided to regulate the matters related to parliamentary elections in a separate law, maintaining the idea of a two-section Constitution ${ }^{24}$.

The second sub-commission of the Constitutional Commission elaborated the draft for the second part "Basic regulations regarding rights and regulations of the citizens". It was discussed both in the sub-commission and in the Constitutional Commission, as well as in the meetings of the Constitutional Assembly. As recorded in memoirs of one of the most prominent authors of the Constitution, Fēlikss Cielēns: "Both sub-commissions and the general constitutional commission were working a lot and with due care. All drafts were discussed in three readings in the sub-commission and then in three readings in the general commission. In the first reading, comprehensive debates took place, and in the remaining two - the articles were discussed"25.

${ }^{22}$ K. Dišlers, Latvijas pagaidu konstitūcija. Vispārīgas piezìmes, „Tieslietu Ministrijas Vēstnesis” 1920, no. 2/3, p. 51.

${ }^{23}$ Protocol no. 2 of the May 11, 1920 meeting of the Constitutional Commission. Unpublished material.

${ }^{24}$ F. Cielēns, Laikmetu maiñā. Atminas un atziņas, Apgāds Memento, Stokholma 1998, p. 107.

${ }^{25}$ Ibidem. 
The second sub-commission of the Constitutional Commission used the August 11, 1919 German Weimar Constitution as the sample for the draft of the second part of the Constitution. In those times, it was considered to be the most modern in Europe and the "final word in the constitutional legislation" ${ }^{26}$. Professor Kārlis Dišlers clearly indicates the Weimar Constitution as the source of inspiration for the second part of the Constitution ${ }^{27}$. Also Fèlikss Cielēns, who in general rather strictly refused the idea that the Constitution of Latvia should be "copied" from the Weimar Constitution ${ }^{28}$, however, with respect to the second part of Constitution, clearly indicated that it "was elaborated by the commission under influence of the German constitution" 29 , and the draft "was basically formed of the relevant parts of the Weimar Constitution" ${ }^{30}$.

\section{Contents of Second Part of Constitution}

The draft of the second part of Constitution prescribed a range of civic and political individual rights and freedoms: immunity of a persona, residence and correspondence, freedom of speech, cognition, faith, movement, assembling, science and art, as well as rights to hold property.

Parallel to that, the draft of the second part of the Constitution contained articles, which prescribed the state responsibility to protect the nationally-cultural autonomy of minorities, monuments of art, history, and nature, as well as marriage as the foundation of the family. The state was assigned with the task to ensure accessibility for sciences and arts, as well as the opportunity for each citizen to study on a mandatory basis for twelve years. Likewise, the second part of the Constitution included the civic equality principle, prohibition of the capital punishment, and grounds for eminent domain of private property. Furthermore, separation of the state from the church was established.

The second part of the Constitution also dealt with the social matters, prescribing that "a strike is a legal means for economic battle" and "the physical and mental work of the Latvian citizens and their production are under protection of the state".

Besides the regulation of the fundamental rights in the draft version, it was planned to establish a prohibition for the citizens of Latvia to receive awards of other countries, as well as the prohibition for the state of Latvia to grant awards. Furthermore, any class category, gentry, and other nobility titles were cancelled. The draft also included a prohibition of operations of the Jesuitical Order and a condition that the mailing service and telegraph is subject to state monopoly,

\footnotetext{
${ }_{26}$ Ā. Šilde, Latvijas vēsture. 1914 -1940, Apgāds Daugava, Stokholma 1976, p. 363.

${ }^{27}$ K. Dišlers, Demokrātiskas valsts iekārtas pamati, A. Gulbis, Rīga 1931, p. 179.

${ }^{28}$ F. Cielēns, Laikmetu maiṇā. Atminas un atziņas, Apgāds Memento, Stokholma 1998, p. 113.

${ }^{29}$ Ibidem.

${ }^{30}$ Ibidem, p. 107.
} 
as well as the principle of that the state owns the railroads, waterways, and other transportation roads of general importance are owned by the state.

The fundamental rights were declared with the disclaimer that they can be restricted with the law if separate interests require that. Also a special article was included, which granted the Cabinet of Ministers with the rights to suspend or limit implementation of a range of norms of the second part of the Constitution subject to exceptional extraordinary situations.

\section{Rejection of Second Part of Constitution}

Unlike the discussions of the first part of the Constitution, where the discussions arose only regarding some issues, consideration of the second part of the Constitution in the Constitutional Assembly progressed in a completely opposite manner - with keen debates over a range of matters.

The referent of the Constitutional Commission, Andrejs Kuršinskis, emphasised that "the second part wishes to proved the first part with the democratic contents, without which the first loses a large share of its significance, because it is clearly visible that if we do not have citizens with civic rights, if the majority of our citizens will remain without the said rights, then our citizens will not be able to further use, develop, and maintain the state system, which is prescribed with the first part of our Constitution"31. Nevertheless, a large part of the members of the Constitutional Assembly were of a different opinion. The member of the Constitutional Assembly, Andrejs Petrevics, admitted: "Here - and pardon my means of expression - there are too many tailings and too little grain. If we pay particular attention to specific sections of the Constitution and see what they actually provide us, then we would have to say that apart from empty promises it does not provide us with anything, that the form of the promises does not contain in itself even the slightest meaningful contents in the majority of the offered articles" 32 . A certain summary regarding the ambience of the Constitutional Assembly was rendered by Arveds Bergs: "This second part to a large extent has the character of a declaration only. Certain theses are set forth, the contents whereof will have to be assigned only in future. The section itself does not contribute anything. Therefore, the question arises - whether the second part is necessary at all" 33 .

Upon considering the second part of the Constitution in the third reading on April 5, 1922, the Constitutional Assembly of Latvia rejected it (62 MPs voted in favour of it, 62 - abstained). Historically, the reasons of why the second part of the Constitution was not adopted are considered the stance of the MPs from Latgale, who were not satisfied with the decision of the majority of the Consti-

\footnotetext{
${ }^{31}$ Report of February 17, $19221^{\text {st }}$ meeting of session V of the Latvian Constitutional Assembly.

${ }^{32}$ Ibidem.

${ }^{33}$ Ibidem.
} 
tutional Assembly to separate the church from the state and to grant the rights of self-government to Latgale ${ }^{34}$. However, a more important was the discussion about the strike as a legal means for battle both economical and political. As the majority of the Constitutional Assembly rejected the inclusion of the strike rights in the second part of the Constitution, the social-democrats abstained in its third reading. To an important extent those were the votes of the social democrats rather than the Latgallians that led to the rejection of the second part of the Constitution ${ }^{35}$.

Upon evaluation of the draft of the second part of Constitution, Ādolfs Šilde has written: "Rejection of the fundamental regulations regarding the civic rights and freedoms was a significant loss in the constitutional operations of the Constitutional Assembly. Even though these same rights later in some laws ensured the Latvian citizens, yet establishment of the said rights in the fundamental law would have had an important significance in establishing principles of a democratic mode of social life in the nation. With adoption of part II of the Constitution, a favour would have been done for the legal structure of Latvia both formally judicially and psychologically/ideologically. The Latvian awareness of rights would have had gained useful impulses" 36 .

\section{Fundamental Rights in Parliamentarism Period}

\section{Discussion about Necessity of Fundamental Rights in Constitu- tion}

The Latvian Constitutional Assembly and also to a large part the governing opinion in the science of jurisprudence in the year 1922 did not perceive the rejection of the second part of the Constitution as a significant setback or constitutional deficiency. Only some authors particularly underlined this deficiency.

The Baltic German lawyer, Baldvins fon Disterlo, upon rendering the first commentary to the Constitution, has indicated: "At first you notice that [in the articles of the constitution] there are no conditions on the general rights and obligations of the citizens, what conditions are usually assumed in laws on the national constitution, wherewith they are ensured with a higher level of independency and unchangeability. In the 1906 fundamental legislation of Russia, the matter on the rights and obligations of its citizens a whole chapter (Chapter VIII) was devoted, consisting of 15 separate articles, and even the temporary

${ }_{34}$ Ā. Šilde, Latvijas vēsture. 1914-1940, Apgāds Daugava, Stokholma 1976, p. 362-363. See also: G. Kusiņšs, Satversme un cilvēktiesības Latvijā, [in:] Cilvēktiesību ìstenošana Latvijā: tiesa un administratīvais process, Latvijas Cilvēktiesību institūts, Rīga 1998, p. 11-12.

${ }^{35}$ V. Cielava, Latvijas Satversme: vēsture un mūsdienas, „Cīṇa” 1989, 1. aprīlis; V. Blūzma, Tiesiskas valsts pirmsākumi Latvijā, „Latvijas Vēsture” 1999, no. 1, p. 47.

${ }^{36}$ Ā. Šilde, Latvijas vēsture. 1914-1940, Apgāds Daugava, Stokholma 1976, p. 363. 
regulations in the form of Article 9, as approved on June 1, 1920 on the political system of Latvia, contained a reference to that in Latvia there is the immunity of a persona and residence, as well as the freedom of press, speech, cognition, strikes, meetings, and assembling, as well as the immunity of correspondence. Considering that the above-mentioned temporary regulations [...] at any cost should be considered as substituted by the current Constitution of the Republic of Latvia [...], a conclusion must be arrived at - according to the general principles of interpreting the laws - that the Article 9 of the regulations was completely withdrawn until in a regular procedure the Parliament would not issue a new deed on the rights and freedoms of the citizens" ${ }^{\prime \prime}$.

However, the professor Maksis Lazersons has assigned it with the popular at the time name of the Constitution Rumpf-Verffassung: "The Latvian Constitutional Assembly, as it has been known, in its time did not adopt the second part of the draft Constitution, and namely, the part, where it was prescribed to ensure all subjective public rights of the citizens [...] With respect to the said condition, in my article "Das Verfassungsrecht Lettlands" I have referred to this constitution as Rumpf-Verffassung. And truly, in all the norms, which are usually contained in other constitution and have remained the "iron fund" of the constitutions, we find the establishment of the political rights of the citizens. In each constitution, even in those of dual monarchies, we can find articles, which to a broader or narrower extent guarantee the rights of the citizens and particularly the so-called freedoms [...] All of this very important material, which in the youngest constitutions, such as, for instance, in case of the 1919 Germany's Constitution, tends to take up the most prominent part, characterising the legal and political essence of the respective counter, has remained completely unregulated in our constitution"38.

The opinion of non-inclusion of the catalogue of the fundamental rights in the Constitution has a significant flaw, objected the most prominent Latvian specialists of governmental rights.

Professor Kārlis Dišlers wrote: "I do not find it that the lack of these conditions should be accounted for such a defect in our constitution, and I do not think that it was. The 1906 fundamental laws of Russia with their Section VIII concerning the rights and obligations of its residents by means of the contents could serve as a sample for a constitution of a democratic republic. The principles of national sovereignty and direct national government, on which the Constitution of the Republic of Latvia has been built, by means of civic guarantees is superior by many times over the declarative conditions on the civic rights, which

${ }^{37}$ B. Disterlo, Juridiskas piezīmes pie Latvijas Republikas Satversmes, „Tieslietu Ministrijas Vēstnesis” 1923, no. 7, p. 2.

${ }^{38}$ M. Lazersons, „Konstitucionāla” likumdošana un Saeimas publisko tiesību komisija, „Jurists” 1928, no. 6, p. 165-166. 
can be found in the constitutions of constitutional monarchies. Overall, I would like to say that in a democratic country, where the national sovereignty principle has been recognised not only theoretically but completely, the rights of democratic elections and direct participation of the nation in the legislation guarantees that the creation and guarantee of a legal system is set in the hands of the nation itself; where, furthermore, the nation in general is sufficiently conscientious and can respect the civic rights and freedoms and perform the responsibilities set for the citizens, - there the regulations of declarative character regarding the rights and obligations of the citizens do not have such an extensive significance at all, as in the constrained countries. In the Tsarist Russia, in the transition from the monarchic absolutism to limited constitutionalism, the significance of such declarative conditions (Section VIII of the 1906 fundamental laws) was large; however nobody will most likely doubt that in the Republic of Latvia, regardless of that its constitution does not contain general conditions on the rights and obligations of the citizens, the civic rights and freedoms are guaranteed on a much higher level than in the former Russia"39.

The views of the professor Kārlis Dišlers were shared also by the lecturer Roberts Akmentiňs: "Whether it is a deficiency in the constitution, whether it is a matter of speaking about Rumpfkonstitution, as some are referring to our constitution. Here we have a simple misunderstanding. And again those, who are asking for a declaration of civic rights are forgetting that the civic rights do not depend on beautifully worded declarations, but rather on other special laws and on the whole political life, which guarantees these rights. There are some countries, whose constitutions and not constitutions alone, even via international treaties bind them to implement the various civic rights (minorities), however they still do not fulfil that. Latvia on the contrary is bound neither with civic rights declarations nor with international rights in a shape of treaties, but nevertheless fulfils these rights" 40 .

\section{Concept of Fundamental Rights}

The discussion on the necessity of the catalogue of the fundamental rights in the Constitution to a large extent displayed the political attitude of the time with respect to the fundamental rights. The guarantee of the fundamental rights catalogue and particularly of the minority rights in the Constitution was actively demanded by the minority representatives, because for them the inclusion of the said rights in the constitution was utterly important for maintaining the national-cultural autonomy.

${ }^{39}$ K.Dišlers, Dažas piezīmes pie Disterlo raksta: „Juridiskas piezīmes pie Latvijas Republikas Satversmes”, „Tieslietu Ministrijas Vēstnesis” 1923, no. 9/10, p. 108.

${ }^{40}$ R. Akmentiňš, Latvijas Satversmes reforma, „Jurists” 1934, no. 5 (57), p. 132. 
However, amongst Latvian jurists, there were no worries about possible infringements of the fundamental rights, because "the constitutional romanticism" dominated the scene. "Constitutional romanticism was expressed as wide-spread longing for a constitutional system and as the rose-coloured aspirations related with this system: it was considered that with the implementation of the constitution and with the participation of representatives, which have been elected by the nation itself, in legislation, from there on only the best laws, and freedom, and general welfare would follow as a self-evident result of the implementation of these good laws"41. Under the influence of such state of mind, the idea of that a democratic republic could be liquidated or that the representatives elected by the nation could adopt laws in contradiction with the fundamental rights of a person was not permissible. Likewise unconsidered were the mechanisms of ways of protecting the constitutional system against the arbitrariness of the legislator or executive power. In theory, the highest legal power of the Constitutional law was not even recognised, because it was considered that it does not hold any practical significance. "Even though many countries in principle recognise the gradation in the laws thus that the constitution is recognised as the primary law, but this principle obtains real significance only in those few countries, where the common courts (such as in the United States of America) or the special supreme courts (like in Czechoslovakia or form. Austria) are assigned with the right to examine the constitutionality of the laws, i.e., concordance of simple laws with the constitutional law" 42 .

Therefore, in the inter-war period both the politicians and the jurists counted on preservation of a democratic republic without inclusion of special norms, for instance, the catalogue of individual fundamental rights, as well as without creating institutional mechanisms, which would adjust the conduct of the legislator or the executive power in accordance with the provisions of the Constitution.

It cannot be denied that during the first years of existence of the democratic republic, the necessity for supplementing the Constitution or institutional mechanisms for protection of the Constitution was not essential. The Parliament adopted a range of laws regulating the individual fundamental rights, as well as established the procedure of their implementation and the state obligations ${ }^{43}$. "The most important tasks of the legislation after the constitutional formation of the democratic republic were related to adopting the laws regulating the most significant political freedoms. [...] Even though they did not possess the power of constitutional laws, the constitutional legal subjects received regulation therein" ${ }^{44}$.

${ }^{41}$ K. Dišlers, Levads administratīvo tiesību zinātnē, Latvijas Universitāte, Rīga 1938, p. 67-68.

${ }^{42}$ Ibidem, p. 99.

${ }^{43}$ M. Lazersons, „Konstitucionāla” likumdošana un Saeimas publisko tiesību komisija, „Jurists” 1928, no. 6, p. 165-168; Ā. Šilde, Pirmā republika, Elpa, Rīga 1993, p. 240.

${ }^{44}$ V. Blūzma, Tiesỉbu attīstìba Latvijas Republikas parlamentārajā posmā (1922-1934), [in:] Latvijas tiesību vēsture (1914-2000). Mācìbu Bookata juridiskajām augstskolām un fakultātēm, ed. D. A. Lēbers, LU žurnāla „Latvijas vēsture” fonds, Rīga 2000, p. 222. 
However the crisis of parliamentarism demonstrated not only the political weakness of the democratic republic itself, but also the groundlessness of the "constitutional romanticism". The discussions of the Constitutional reform, which to a large extent concluded with the establishment of the authoritarian regime of Kārlis Ulmanis, invited to allocate greater authority for the executive power, as well as decrease the rights of the minorities and the civic and political rights established for individuals. Therefore, it is not by accident, that over the course of reform of the Constitution, in 1934, a few days before the coup d'etat, the social-democrats still offered to supplement the Constitution with the norms of fundamental rights, however the Baltic Germans submitted a proposal to create the State court, which would implement in essence the functions of a constitutional court ${ }^{45}$.

\section{Fundamental Rights in Latvian Constitution}

On July 6, 1993, upon assembling for the first sitting of the newly-elected $5^{\text {th }}$ parliamentary convocation, the 1922 Constitution became fully effective. Relatively quickly, the lack of the fundamental rights catalogue was identified as the main deficiency. This deficiency was accentuated by the international experts: "[The Constitution] does not regulate other matters, it particularly is lacking in the human rights norms. [...] The major deficiency in the Latvian constitutional rights currently is the fact that the human rights do not formally hold a constitutional rank"46.

When commenting this aspect, the Chief of the Legal Bureau of Parliament, Gunārs Kusiňš justifiably indicated: "Even though the Constitution does not contain any human rights guarantees to an extent as it is used to in the Western Europe, it is nevertheless wrong to consider that the Constitution does not mention anything about the human rights. Articles 8 and 9 of the Constitution establish the civic rights to vote and be elected in the Parliament. Article 65 of the Constitution prescribes that not less than $1 / 10$ of the voters can submit a draft law at the Parliament. Article 80 of the Constitution establishes the rights of the citizens to participate in a referendum, and Article 82 of the Constitution prescribes the equality of the citizens before the court and law. Of course, it is a very incomplete regulation" ${ }^{47}$.

Meanwhile, interesting conclusions can be drawn from the decision of the Constitutional Court in the case No. 2007-10-0102. In this decision, the Constitutional Court concluded that upon the Constitution taking effect on November

\footnotetext{
${ }^{45}$ Report of May 4, $19345^{\text {th }}$ meeting of session IX of the IV ${ }^{\text {th }}$ Saeima of the Republic of Latvia.

${ }^{46}$ Atbildes uz ANO Cilvēktiesību komitejas locekḷu jautājumiem, „Cilvēktiesību Žurnāls” 1996, no. 2 , p. $78-79$.

${ }^{47}$ Ibid, 78. For more inf. see also: G. Kusiņš, Satversme un cilvēktiesības Latvijā, [in:] Cilvēktiesību istenošana Latvijā: tiesa un administratīvais process, Latvijas Cilvēktiesību institūts, Rīga 1998, p. 11-17 .
} 
7, 1922, the temporary regulations of the Latvian political system did not become fully legally ineffective.

The Constitutional Court indicated: "The Latvian Senate practice indicates that the temporary regulations of the Latvian political system did not become ineffective automatically to the full extent, but rather to such an extent as the temporary regulations were substituted with the legal norms included in the Constitution".

Article 9 of the temporary regulations of the Latvian political system prescribed: "the case law of the Senate of Latvia shows that the Provisional Rules of the Regime of the State of Latvia did not became invalid automatically to full extent, but only insofar as the norms of the provisional rules were substituted by the legal norms included in the Satversme".

Article 9 of the Provisional Rules of the Regime of the State of Latvia provided: "Inviolability of persons and lodging, freedom of press, speech, conscience, strike, meeting and association, inviolability of correspondence exist in Latvia and shall be ensured and established by the respective laws". The list of the basic rights was not included in the Satversme on November 7, 1922 when it became effective".

The Administrative Department of the Senate of Latvia, in the Judgment of November 20, 1929 No. 64 that was made in a case on registration of trade unions, started the list of the valid legal norms by the norm of a constitutional rank - Article 9 of the Provision Rules of the Regime of the State of Latvia that provided for freedom of association. The Administrative Department of the Senate also indicated that "the slogan of a deductive nature" included in Article 9 of the Provisional Rules "can only be interpreted in the sense that manifestation of this freedom cannot come in conflict with the existent laws" [...].

Consequently, the Provisional Rules on the Regime of the State of Latvia became invalid in the moment when the issues dealt in these Rules was regulated in norms of another act of a constitutional rank ${ }^{48}$.

${ }^{48}$ Par likuma „Par pilnvarojumu Ministru kabinetam parakstīt 1997. gada 7. augustā parafēto Latvijas Republikas un Krievijas Federācijas līguma projektu par Latvijas un Krievijas valsts robežu” un likuma „Par Latvijas Republikas un Krievijas Federācijas līgumu par Latvijas un Krievijas valsts robežu” 1. panta vārdu ,ievērojot Eiropas Drošības un sadarbības organizācijas pieņemto robežu nemainības principu” atbilstību Latvijas PSR Augstākās padomes 1990. gada 4. maija deklarācijas „Par Latvijas Republikas neatkarības atjaunošanu” preambulai un 9. punktam un 2007. gada 27. martā parakstītā Latvijas Republikas un Krievijas Federācijas līguma par Latvijas un Krievijas valsts robežu un likuma „Par Latvijas Republikas un Krievijas Federācijas līgumu par Latvijas un Krievijas valsts robežu” atbilstību Latvijas Republikas Satversmes 3. pantam: Satversmes tiesas 2007. gada 29. novembra spriedums lietā Nr. 200710-0102, „Latvijas Vēstnesis” no. 193 (3769), Sprieduma 59.2. punkts. Spriedumā citēto Latvijas Senāta spriedumu sk.: Latvijas Senāta spriedumi (1918-1940). 3. sējums. Senāta Administratīvā departamenta spriedumi (1926-1930), Latvijas Republikas Augstākā tiesa, Senatora Augusta Lēbera fonds, Rīga 1997, p. 1200. Decision translation in English: http://www.satv.tiesa.gov.lv/upload/judg_2007_10_0102.htm. 
From this conclusion made by the Constitutional Court, it can be clearly derived that it considers the Article 9 of the temporary regulations of the Latvian political system as an effective norm of constitutional rank up to the moment when the Constitution was supplemented with the fundamental rights catalogue. Therefore, it can be considered, that before adopting Section 8 of the Constitution, Article 9 of the temporary regulations of the Latvian political system was effective and established the fundamental rights.

The opinion of the Constitutional Court, however, contradicts the jurisprudence writings produced in the inter-war period stating that "the above-mentioned temporary regulations [...] in any case are to be considered as replaced with the current Constitution of the Republic of Latvia, because the latter does not contain the slightest reference to which of the said regulations would remain effective further on, therefore a conclusion must be reached - according to the general principles of interpreting the laws - that the Article 9 of the regulations is completely cancelled before the Parliament issues a new deed on civic rights and freedoms in a regular legislative procedure" ${ }^{\prime 9}$. However, it cannot be denied that the Constitutional Court has justified its conclusion sufficiently well.

The Constitutional Court widely analysed the validity of the respective norm, inter alia, writing: "The Satversme of the Republic of Latvia that was passed on February 15, 1922 does not provide for any legal rules that would regulate validity of the provisional constitution. Such legal norms were not included in the Law "On Enactment of the Satversme of the Republic of Latvia".

"Consequently, the Constitutional Assembly of Latvia did not expressis verbis repeal the rules of the second provisional constitution with the enactment of the Satversme. [...] Consequently, the Provisional Rules on the Regime of the State of Latvia became invalid in the moment when the issues dealt in these Rules was regulated in norms of another act of a constitutional rank"50. Likewise, the verdict of the Latvian Senate is a sufficiently convincing condition to justify the conclusions made by the Constitutional Court.

${ }^{49}$ B. Disterlo, Juridiskas piezīmes pie Latvijas Republikas Satversmes, „Tieslietu Ministrijas Vēstnesis” 1923 , no. 7, p. 2.

${ }^{50}$ Par likuma „Par pilnvarojumu Ministru kabinetam parakstīt 1997. gada 7. augustā parafēto Latvijas Republikas un Krievijas Federācijas līguma projektu par Latvijas un Krievijas valsts robežu" un likuma „Par Latvijas Republikas un Krievijas Federācijas līgumu par Latvijas un Krievijas valsts robežu” 1. panta vārdu „ievērojot Eiropas Drošības un sadarbības organizācijas pieņemto robežu nemainības principu” atbilstību Latvijas PSR Augstākās padomes 1990. gada 4. maija deklarācijas „Par Latvijas Republikas neatkarības atjaunošanu” preambulai un 9. punktam un 2007. gada 27. martā parakstītā Latvijas Republikas un Krievijas Federācijas līguma par Latvijas un Krievijas valsts robežu un likuma „Par Latvijas Republikas un Krievijas Federācijas līgumu par Latvijas un Krievijas valsts robežu” atbilstību Latvijas Republikas Satversmes 3. pantam: Satversmes tiesas 2007. gada 29. novembra spriedums lietā Nr. 2007-10-0102, „Latvijas Vēstnesis” Nr 193 (3769), Sprieduma 59. punkts. 


\section{Conclusions}

In the inter-war period, the catalogue of the fundamental rights was not considered as a significant component of the constitution text. Likewise, at the times, the norms of the catalogue were generally perceived as "declarative slogans", which had little practical significance. Much greater importance was assigned by the politicians and jurists to the laws adopted by the parliament with regards to the procedure of implementing certain fundamental rights.

Meanwhile, the experience of a democratic judicial state both in Latvia and across Europe has proved the groundlessness of such opinion. Currently, most likely, few will doubt that it is the fundamental rights catalogue and the guarantees included therein that constitute the most important part of the constitution.

The road of Latvia towards inclusion of the fundamental rights catalogue in the constitution started with proclamation of the state on November 18, 1918. The initial transitional constitutions already included according to their laconic style rather extensive guarantees of the fundamental rights. Unfortunately, the second part of the Constitution was not adopted, leaving the regulation of this matter for the upcoming generations, which was completed only ten years ago. 